\title{
PERANCANGAN SISTEM PENGOLAHAN DATA TIMBANG PABRIK MINYAK SAWIT (CPO MILL) \\ DENGAN BAHASA PEMROGRAMAN VISUAL BASIC 6.0 PADA PT HINDOLI BANYUASIN PALEMBANG SUMATERA SELATAN
}

\author{
Reni Nursyanti \\ Program Studi Teknik Informatika \\ Fakultas Ilmu Komputer \\ Universitas Bandar Lampung \\ Jln. Z.A. Pagar Alam No.26 Labuhan Ratu Bandar Lampung 35142 \\ Telp. (0721) 701463, (0721) 701979 Fax. (0721) 701467 Web. www.ubl.ac.id
}

\section{PENDAHULUAN}

\subsection{Latar Belakang}

Seiring dengan perkembangan zaman, kemajuan dan perkembangan ilmu pengetahuan dan teknologi telah mempengaruhi cara hidup manusia. Perkembangan teknologi informasi memacu suatu cara baru dalam berbagai bidang usaha. Teknologi komputer digunakan untuk membantu keterbatasan manusia dalam memecahkan berbagai masalah yang dihadapi, terutama untuk pekerjaan yang bersifat pengulangan.

Teknologi komputer digunakan untuk mengolah data, termasuk memproses, mendapatkan, menyusun, menyimpan, memanipulasi data dalam berbagai cara untuk menghasilkan informasi yang berkualitas, yaitu informasi yang relevan, cepat, akurat dan tepat waktu, sehingga akan meningkatkan produktivitas kerja dan membantu dalam proses pengambilan keputusan.

Teknologi komputer memiliki pengaruh besar bagi jalannya roda pekerjaan suatu perusahaan. Tidak terkecuali bagi PT Hindoli, yang bergerak dalam usaha perkebunan kelapa sawit dan pabrik minyak sawit (CPO Mill). Salah satunya adalah komputer digunakan untuk membantu bagian administrasi data timbang Tandan Buah Segar (TBS) sawit.

Permasalahan yang dihadapi oleh perusahaan ini antara lain, Sering terjadinya kesalahan pencatatan angka timbang, lamanya proses pengolahan data dan terlambatnya pembuatan laporan, dapat menyebabkan proses produksi CPO terganggu. Keterlambatan pembuatan laporan menyebabkan bagian pembukuan terlambat melaksanakan pembayaran kepada petani atas pembelian buah sawit / Tandan Buah Segar (TBS) sawit, hal ini memicu ketidakpuasan petani dan dapat menimbulkan kerugian pihak perusahaan ataupun petani sawit.

Untuk meningkatkan produktivitas kerja di PT Hindoli Banyuasin Pelembang Sumatera Selatan, serta membangun sistem pengolahan data timbang yang lebih efektif dan efisien diperlukan perencanaan dan konsep sistem yang lebih baik.

Berdasarkan uraian di atas maka peneliti melakukan analisa pada sistem yang sedang berjalan dan merancang sistem baru terkomputerisasi. Untuk meningkatkan akurasi data dan otomatisasi pengolahan data timbang, peneliti menggunakan sensor beban (load cell) dalam akuisisi data timbang. Peneliti membuat laporan penelitian ilmiah ini dengan judul: "Perancangan Sistem Pengolahan Data Timbang Pabrik Minyak Sawit (CPO Mill) Dengan Bahasa Pemrograman Visual Basic 6.0 Pada PT Hindoli Banyuasin Palembang Sumatera Selatan".

\subsection{Identifikasi Masalah}

Dari latar belakang yang telah dikemukan di atas, maka peneliti merumuskan masalah sebagai berikut :

1. Bagaimana melakukan akuisisi data timbang untuk meningkatkan akurasi dan otomatisasi 
dalam sistem pengolahan data timbang pabrik minyak sawit (CPO Mill) pada PT Hindoli Banyuasin Palembang Sumatera Selatan?.

2. Bagaimana menjaga integritas data timbang terhadap petugas dilapangan dalam sistem pengolahan data timbang pabrik minyak sawit (CPO Mill) pada PT Hindoli Banyuasin Palembang Sumatera Selatan?.

\subsection{Batasan Masalah}

Berdasarkan latar belakang dan permasalahan yang dikemukakan di atas, peneliti membatasi pembahasan pada :

a. Perancangan sistem pengolahan data timbang yang terkomputerisasi pada PT Hindoli Banyuasin Palembang Sumatera Selatan.

b. Timbangan yang digunakan berjenis Jembatan Timbang (Weighbridge) yang biasanya dipakai untuk menimbang truk beserta muatannya.

c. Mengimplementasikan hasil rancangan dalam bentuk perangkat lunak sistem aplikasi komputer dengan memakai Bahasa Pemrograman Visual Basic 6.0.

d. Pemakaian Sistem Pengelola Basis Data (Database Management System, DBMS) MySQL Server 5.0.

e. Penggunaan Sensor Beban (load cell) dalam akuisisi data timbang.

\subsection{Tujuan Penelitian} adalah :

Maksud dan tujuan penelitian ilmiah ini Perancangan Sistem Pengolahan Data Timbang Pabrik Minyak Sawit (CPO Mill) terkomputerisasi pada PT Hindoli Banyuasin Palembang Sumatera Selatan.

a. Meningkatkan akurasi data dan otomatisasi pengolahan data timbang dalam sistem pengolahan data timbang pabrik minyak sawit (CPO Mill) pada PT Hindoli Banyuasin Palembang Sumatera Selatan?.

b. Menjaga integritas data timbang terhadap petugas dilapangan dalam sistem pengolahan data timbang pabrik minyak sawit (CPO Mill) pada PT Hindoli Banyuasin Palembang Sumatera Selatan?. c. Meningkatkan produktivitas perusahaan dalam penyajian informasi yang cepat, tepat, akurat dan sesuai dengan kebutuhan.

d. Menambah pengetahuan dan pengalaman peneliti dalam analisis dan perancangan suatu sistem informasi.

\subsection{Kerangka Pemikiran}

Dalam kerangka pemikiran ini peneliti mencoba untuk menjelaskan pengertian judul yang dipilih dalam penelitian Penelitian ini.

1. Perancangan

Perancangan adalah proses, cara, perbuatan merancang. (Kamus Besar Bahasa Indonesia, Dekdikbud, 1990:725)

2. Sistem

Sistem adalah Sekumpulan hal atau kegiatan atau elemen atau subsistem yang saling bekerjasama atau yang dihubungkan dengan cara-cara tertentu sehingga membentuk satu kesatuan untuk melaksanakan suatu fungsi guna mencapai tujuan. (Edhy Sutanta, 2003:4)

3. Perancangan Sistem

Perancangan sistem adalah strategi untuk memecahkan masalah dan mengembangkan solusi terbaik bagi permasalahan itu. (Adi Nugroho, 2002:139)

4. Perancangan Sistem Informasi

Perancangan sistem informasi merupakan suatu sistem yang dirancang untuk menyajikan atau memberikan informasi yang berguna dan bermanfaat bagi pemakai informasi tersebut, yang berorientasi pada pengambil keputusan yang diperlukan oleh manajemen guna merencanakan, mengawasi, menilai serta menjalankan aktivitas dari suatu organisasi tersebut.

5. Visual Basic 6.0

Visual Basic 6.0 atau Microsoft Visual Basic 6.0 atau disingkat VB 6.0 adalah salah satu bahasa pemrograman yang bekerja dalam lingkungan Microsoft Windows yang banyak digunakan saat ini. Karena Visual Basic merupakan bahasa pemrograman maka dimengerti oleh 
sistem komputer untuk melaksanakan tugas-tugas tertentu.

6. Pengolahan Data

Pengolahan data adalah suatu proses menerima data sebagai masukan (input) memproses (processing) dengan menggunakan program tertentu dan mengeluarkan hasil proses data tersebut dalam bentuk informasi (output).

7. Data Timbang

Data timbang adalah angka yang dihasilkan oleh alat jembatan timbang (weighbridge) pada saat proses penimbangan terhadap mobil beserta muatannya.

8. Minyak Sawit

Minyak sawit adalah minyak yang dihasil dari proses pengolahan dengan cara tertentu pada buah pohon kelapa sawit.

9. Pabrik Sawit

Pabrik sawit atau disebut CPO Mill (Crude Palm Oil Mill) adalah tempat untuk melakukan proses pengolahan buah sawit menjadi minyak sawit.

10. Sawit

Sawit atau Pohon Kelapa Sawit (Palm Tree) adalah sejenis pohon palem yang dapat menghasilkan buah yang mempunyai kandungan minyak. Buah yang dihasilkan pohon kelapa sawit disebut buah sawit atau sering disebut tandan buah segar (TBS) sawit.

\section{TINJAUAN PUSTAKA}

\subsection{Konsep Dasar Sistem}

\subsubsection{Definisi Sistem}

Definisi sistem berkembang sesuai dengan konteks dimana pengertian sistem digunakan. Ada 2 pandangan pendekatan di dalam mendefinisikan sistem, yaitu pendekatan yang menekankan pada prosedurnya dan pendekatan yang menekankan pada komponen atau elemennya.

Pendekatan sistem yang menekankan pada prosedur mendefinisikan sistem sebagai berikut: "Suatu Sistem adalah suatu jaringan kerja dari prosedur-prosedur yang saling berhubungan, berkumpul bersama-sama untuk melakukan suatu kegiatan atau untuk menyelesaikan suatu sasaran tertentu". Pendekatan sistem yang merupakan jaringan kerja dari prosedur lebih menekankan urut-urutan operasi di dalam sistem.

\subsubsection{Definisi Sub Sistem}

Gordon B. Davis, mendefinisikan sistem dibagi menjadi beberapa factor atau unsur-unsur kedalam subsistem-subsistem.

Norman L. Enger, mendefinisikan suatu sub-sistem adalah serangkaian kegiatan yang dapat ditentukan identitasnya.

\subsubsection{Definisi Prosedur}

Suatu prosedur adalah urut-urutan yang tepat dari tahapan-tahapan instruksi yang menerangkan apa (what) yang harus dikerjakan, siapa (who) yang mengerjakan, kapan (when) dikerjakan dan bagaimana (how) mengerjakannya. (Jerry FitzGerald, 1981:6).

\subsubsection{Model Umum Suatu Sistem}

Model umum suatu sistem terdiri dari 2 (dua) model yaitu :

a. Model Sistem Sederhana

Model sistem ini terdiri atas masukan (input), pengolah (proses), dan keluaran (output), sebagaimana ditunjukan Gambar 2.1 dibawah ini:

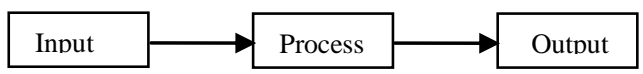

Gambar 2.1 Model Sistem Sederhana

a. Model Sistem Banyak Masukan (Input) dan Keluaran (Output)

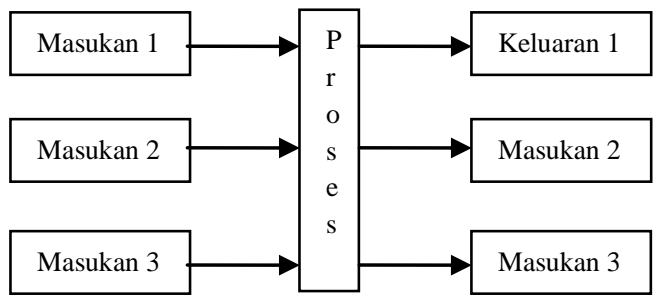

Gambar 2.2 Model Sistem dengan banyak Masukan dan Keluaran 


\subsection{Konsep Dasar Informasi}

\subsubsection{Definisi Informasi}

Informasi adalah hasil dari pengolahan data menjadi bentuk yang lebih berguna bagi yang menerimanya yang menggambarkan suatu kejadian-kejadian nyata dan dapat digunakan sebagai alat bantu untuk pengambilan suatu keputusan. (Teguh Wahyono, 2004: 3).

\subsubsection{Arsitektur Informasi}

Arsitektur Informasi adalah suatu pemetaan dari rencana kebutuhan-kebutuhan informasi didalam suatu organisasi (Turban, McLean, Wetherbe, 1999).

\subsection{Konsep Dasar Sistem Informasi}

\subsubsection{Definisi Sistem Informasi}

Sistem informasi adalah suatu sistem di dalam suatu organisasi yang mempertemukan kebutuhan pengelohan transaksi harian, pendukung operasi, bersifat manajerial, dan kegiatan strategi dari suatu organisasi dan menyediakan pihak luar tertentu dengan laporanlaporan yang diperlukan. (Jogiyanto. HM, 1999 : 11).

Menentukan tingkat kelayakan kebutuhan sistem baru tersebut ditinjau dari beberapa aspek, diantaranya ekonomi, teknik, operasional, dan hukum. (Hanif Al Fatta, 2007 : 45)

\subsubsection{Tahapan Analisa Sistem}

Di dalam tahap analisis sistem terdapat langkah-langkah dasar yang harus dilakukan oleh analis sistem sebagai berikut ini :

1. Mengidentifikasi masalah (Identify)

Mengidentifikasi masalah merupakan langkah pertama yang dilakukan dalam tahap analisis sistem. Masalah dapat di definisikan sebagai suatu pernyataan yang diinginkan untuk dipecahkan. Masalah inilah yang menyebabkn sasaran dari sistem yang tidak dapat dicapai.

2. Memahami kerja sistem yang ada (Understand)

\subsubsection{Definisi Basis Data}

Definisi Basis Data menurut Mc. Leod, Basis Data merupakan suatu kumpulan data yang saling terintegrasi, diatur dan disimpan menurut suatu cara yang memudahkan pengambilan kembali.

a. tabel Nilai juga memiliki field NPM, tetapi field NIM disini merupakan field foreign key yang digunakan untuk menghubungkan tabel Mahasiswa dengan tabel Nilai.

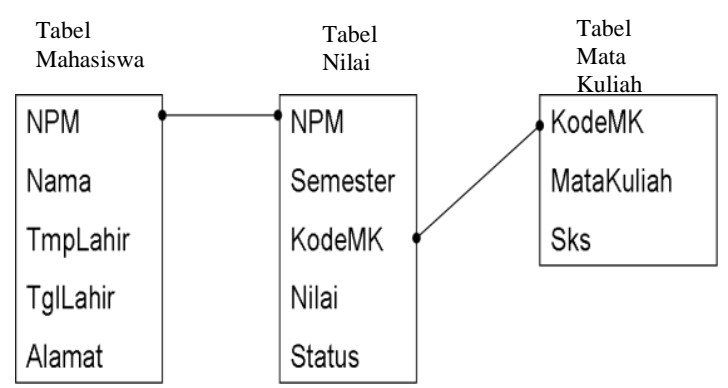

Catatan:

- Field NPM pada Tabel Mahasiswa adalah Primary Key

- Field NPM pada Tabel Nilai adalah Foreign Key

Gambar 2.5. Contoh Primary Key dan Foreign Key

\subsection{Konsep Dasar Normalisasi}

\subsubsection{Pengertian Normalisasi}

Normalisasi adalah sebuah teknik perancangan yang banyak digunakan sebagai pemandu dalam merancang basis data relasional. Pada dasarnya, normalisasi adalah suatu cara mengambarkan data dalam bentuk baris (record) dan kolom (field) dengan menghilangkan kelompok berulang, lalu menghilangkan data yang terduplikasi dari tabel relasional.

\subsubsection{Tujuan Normalisasi}

Adapun tujuan dari normalisasi adalah :

1. Mengatur data dalam kelompok-kelompok sehingga masing-masing kelompok hanya menangani bagian kecil sistem. 
2. Meminimalkan jumlah data berulang dalam basis data.

3. Membuat basis data yang datanya diakses dan dimanipulasi secara cepat dan efisien tanpa melupakan integritas data.

\subsection{Konsep Dasar Sistem Basis Data}

\subsubsection{Pengertian Dasar Sistem Basis Data}

Basis data hanyalah sebuah objek yang pasif, tidak akan berguna jika tidak ada pengelola / penggeraknya, yaitu program aplikasi. Karena itu, secara umum sebuah sistem basis data merupakan sistem yang terdiri atas kumpulan file (tabel) yang saling berhubungan (dalam sebuah basis data di sebuah sistem komputer) dan sekumpulan program (DBMS) yang memungkinkan beberapa pemakai dan atau program lain untuk mengakses dan memanipulasi file-file (tabel-tabel) tersebut.

\subsubsection{Definisi Sistem Basis Data}

Sistem Basis Data adalah suatu sistem penyusunan dan pengelolaan record-record menggunakan komputer untuk menyimpan atau merekam serta memelihara data operasional lengkap sebuah organisasi/perusahaan, sehingga mampu menyediakan informasi yang optimal yang diperlukan pemakai untuk proses pengambilan keputusan.

\subsubsection{Komponen Sistem Basis Data}

Dalam sebuah sistem basis data, secara lengkap akan terdapat komponen-komponen utama sebagai berikut :

1. Perangkat Keras (Hardware)

2. Sistem Operasi (Operating System)

3. Basis Data (Database)

4. Sistem Pengelola Basis Data (DBMS)

5. Aplikasi (Perangkat lunak) lain

6. Pemakai (User)

\subsection{Konsep Dasar Sistem Pengelola Basis Data}

\subsubsection{Pengertian Dasar Sistem Pengelola Basis Data}

Sistem Pengelola Basis Data, sering disebut DBMS (database management system) adalah perangkat lunak yang menangani semua akses terhadap basis data dan menyediakan antarmuka pemakai (user interface) terhadap Sistem Basis Data. DBMS merupakan perantara bagi pemakai dengan basis data dalam media penyimpan. Cara berinteraksi antara pemakai dengan basis data tersebut diatur dalam suatu bahasa khusus yang ditetapkan oleh pembuat DBMS. Bahasa ini dapat disebut Bahasa Basis Data (Database Language) yang terdiri atas sejumlah perintah (statement) yang diformulasikan dan dapat diinstruksikan oleh pemakai (user) dan dikenali atau diproses oleh DBMS untuk melakukan suatu aksi / pekerjaan tertentu. Contoh bahasa basis data adalah SQL (Structured Query Language).

Sebuah bahasa basis data (database language) biasanya dapat dipilah kedalam 2 bentuk yaitu :

- Data Definition Language (DDL)

- Data Manipulation Languate (DML)

\subsubsection{Data Definition Language (DDL)}

Struktur / Skema basis data yang menggambarkan / mewakili desain basis data secara keseluruhan dispesifikasikan dengan bahasa khusus yang disebut Data Definition Language (DDL). Dengan bahasa inilah kita dapat membuat tabel baru, membuat indeks, mengubah tabel, menentukan struktur penyimpanan tabel.Hasil dari kompilasi perintah DDL adalah kumpulan tabel yang disimpan dalam file khusus yang disebut Kamus Data (Data Dictionary).

Kamus data merupakan suatu metadata (superdata) yaitu data yang mendePenelitiankan data sesungguhnya. Kamus data ini akan selalu diakses dalam suatu operasi basis data sebelum suatu file data yang sesungguhnya diakses.

\subsubsection{Data Manipulation Language (DML)}

Merupakan bentuk bahasa basis data yang berguna untuk melakukan manipulasi dan pengambilan data pada suatu basis data. Manipulasi data dapat berupa :

- penyisipan / penambahan data baru ke suatu basis data

- Penghapusan data dari suatu basis data 
- Pengubahan data di suatu basis data.

Data Manipulation Language (DML) merupakan bahasa yang bertujuan memudahkan pemakai untuk mengakses data sebagaimana direpresentasikan oleh mode data. Ada 2 jenis DML yaitu :

1. Prosedural, yang mensyaratkan agar pemakai menentukan, data apa yang diinginkan serta bagaimana cara mendapatkannya.

2. Non Prosedural, yang membuat pemakai dapat menentukan data apa yang diinginkan tanpa menyebutkan bagaimana cara mendapatkannya.

\subsubsection{Fungsi-Fungsi Sistem Pengelola Basis Data}

Biasanya dalam suatu sistem pengelola basis data (DBMS) terdapat fungsi-fungsi sebagai berikut :

1. Data Definition, DBMS harus dapat mengolah pendefinisian data.

2. Data Manipulation, DBMS harus dapat menangani permintaan dari pemakai untuk mengakses data.

3. Data Security \& Integrity (keamanan dan integritas data), DBMS harus dapat memeriksa security dan integrity data yang didefinisikan oleh Database Administrator (petugas yang bertanggung jawab terhadap pengelolaan basis data).

4. Data Recovery \& Concurency, DBMS harus dapat menangani kegagalan-kegagalan pengaksesan basis data yang dapat disebabkan oleh kesalahan sistem, kerusakan simpanan data.

5. Data Dictionary, DBMS harus menyediakan data dictionary (kamus data).

6. Performance, DBMS harus menangani unjuk kerja dari semua fungsi seefisien mungkin.

\subsubsection{Komponen Sistem Pengelola Basis Data (Komponen DBMS)}

Sebuah DBMS (Database Management System) umumnya memiliki sejumlah komponen fungsional (modul) seperti :

1. File Manager, yang mengelola ruang dalam simpanan data (disk) dan struktur data yang dipakai untuk merepresentasikan informasi yang tersimpan dalam simpanan data (disk). Sebenarnya Sistem Operasi (tempat dimana DBMS diaktifkan) juga memiliki modul File Manager, tetapi File Manager di DBMS lebih difokuskan pada efisiensi dan efektivitas penyimpanan.

2. Database Manager, yang menyediakan interface (antarmuka) antara data low-level yang ada di basis data dengan program aplikasi dan kueri (query) yang diberikan ke sistem.

3. Query Processor, yang menterjemahkan perintah-perintah dalam Query Language (perintah kueri) ke perintah low-level yang dapat dimengerti oleh Database Manager. Disamping itu, Query Processor akan akan mentransformasikan permintaan user (pemakai) ke bentuk yang lebih efiesien, sehingga query menjadi lebih efisien.

4. DML Precompiler, yang mengkonversi perintah DML yang ditambahkan dalam sebuah program aplikasi ke pemanggilan prosedur normal dalam bahasa induk. Precompiler ini akan berinteraksi dengan query processor.

5. DDL Compile, yang mengkonversi perintahperintah DDL kedalam sekumpulan tabel yang mengandung metadata. Tabel-tabel ini kemudian disimpan dalam kamus data.

1) Sensor Beban (Load Cell)

Sebuah alat yang akan mengkonversi tegangan/beban mekanik menjadi signal elektrik. Prinsip yang diterapkan adalah mengikuti prinsip bahwa konduktor akan memiliki resistansi yang berbeda pada sisi panjang ataupun mendatarnya.Gaya yang dikenakan pada bidang ukur akan menyebabkan bidang membengkok, bengkokan ini akan mendistorsi ukuran bidang, dan akan terjadi perubahan resistansi. Perubahan resistansi ini akan disinyalir oleh sirkit yang ada.

2) Indikator Timbangan (Weighbridge Indicator)

Suatu alat yang dapat memproses sinyal arus tegangan/beban analog dan memproses sinyal tersebut kebentuk digital sehingga terbentuk angka digital sebagai hasil timbangan.

$\begin{array}{clcc}\text { Pada } & \text { umumnya Indikator } & \text { Timbangan } \\ \text { terdiri } & \text { dari seperangkat } & \text { komponen }\end{array}$ 
mikroprosessor untuk memproses sinyal arus tegangan, yang mempunyai fungsi keluaran dengan memakai antarmuka RS232, yang dapat digunakan sebagai antarmuka dengan sebuah komputer pribadi (personal computer) dalam mentransfer angka digital hasil timbang.

3) Kotak Hubung (Summing Junction Box)

Suatu alat untuk menyatukan beberapa sinyal sensor beban sehingga didapat satu keluaran sinyal, selanjutnya sinyal keluaran tersebut dikirim ke Indikator Timbangan. Junction box juga berfungsi untuk menyesuaikan / menyetel sensor beban agar jembatan timbang menjadi seimbang (balance).

\section{METODOLOGI PENELITIAN}

\subsection{Metodologi Penelitian}

Metode yang digunakan dalam penelitian ini adalah dengan menggunakan teknik deskriptif yaitu penelitian yang didasarkan pengamatan dengan tujuan pengumpulan data, membuat dePenelitian permasalahan yang telah diidentifikasi, sampai analisis data yang di peroleh dari perusahaan tempat penelitian dilakukan. Dengan menggunakan teknik deskriptif peneliti dapat menjelaskan situasi dan keadaan yang terjadi pada saat peneliti melaksanakan penelitian.

\subsection{Metode Pengumpulan Data}

Metode yang digunakan dalam penelitian ilmiah ini adalah dengan melakukan Studi Pustaka (Library Research), Studi Lapangan (Field Research), mengadakan Wawancara (Interview), Studi Dokumen (Document Research), Studi Percobaan (Experiments Research).

\subsubsection{Studi Pustaka (Library Research)}

Penelitian kepustakaan dilakukan dengan membaca panduan-panduan buku, makalah ilmiah, jurnal-jurnal dan catatan-catatan berhubungan dengan topik yang diteliti, dibaca, dipelajari serta disimpulkan untuk kemudian dijadikan bahan acuan dan data.

\subsubsection{Studi Lapangan (Field Research)}

Studi lapangan dilakukan mengadakan penelitian secara langsung dengan memakai metode sebagai berikut :

a. Observasi (Pengamatan Langsung)

Pengumpulan data dengan pengamatan secara langsung pada obyek penelitian guna mendapatkan gambaran secara menyeluruh dan jelas pada bagian Pengolahan Data Timbang Pabrik Minyak Sawit pada PT Hindoli Banyuasin Palembang Sumatera Selatan.

b. Wawancara (Interview)

Wawancara adalah suatu percapakan langsung dengan tujuan-tujuan tertentu dengan menggunakan format tanya-jawab. Pengumpulan data dilakukan dengan tanya-jawab pada pimpinan PT Hindoli dan bagian administrasi serta operator jembatan timbang PT Hindoli.

\section{c. Dokumentasi}

Pengumpulan dokumen, formulir-formulir yang digunakan dan pencatatan data yang berhubungan dengan sistem yang diamati. Dokumen yang dikumpulkan antara lain Receiving Scale Ticket, FFB Grading Form, Formulir Penilaian Kualitas TBS, Surat Pengantar Buah (SPB).

\subsubsection{Studi Percobaan (Experiments Research)}

Peneliti melakukan percobaan-percobaan terhadap peralatan yang digunakan seperti Sensor Beban (Load Cell) dalam hubungannya dengan akuisisi data timbang.

\subsection{Metode Analisis Data}

Metodologi analisis yang dipergunakan oleh peneliti dalam menganalisa sistem Pengolahan Data Timbang Pabrik Minyak Sawit pada PT Hindoli adalah :

\subsubsection{Metodologi Pemecahan Fungsional (Functional Decomposition Methodologies)}

Metodologi ini menekankan pada pemecahan dari sistem ke dalam sub- sistemsubsistem yang lebih kecil, sehingga akan lebih mudah untuk dipahami. 


\subsubsection{Metodologi Orientasi Aliran Data (Data Flow Oriented Methodologies)}

Metodologi ini secara umum didasarkan pada pemecahan sistem ke dalam modul-modul berdasarkan tipe elemen data dan tingkah laku logika modul tersebut dalam sistem. Dengan metodologi ini, sistem secara logika digambarkan dari arus data dan hubungan antar fungsinya di dalam modul-modul sistem.

\subsection{Metode Pengembangan Sistem}

Adapun metode yang digunakan dalam pengembangan perangkat lunak ini adalah berdasarkan Paradigma Waterfall (Classic Life Cycle).

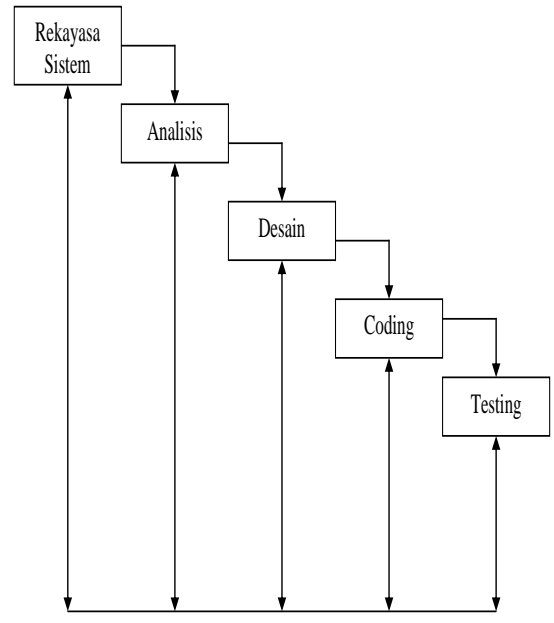

Gambar 3.1 Paradigma Waterfall (Classic Life Cycle)

Berikut adalah penjelasan dari tahapan paradigma Waterfall :

1. Rekayasa Sistem, pada tahap ini peneliti mengunjungi perusahaan yang bersangkutan untuk penelitian. Dengan mewawancarai pihak yang berhubungan dengan bagian pengelola data timbang di PT. Hindoli.

2. Analisis, pada tahap ini peneliti melakukan analisis perangkat lunak, analisis kebutuhan fungsional, membuat DFD dan membuat kamus data.

3. Desain, pada tahap ini peneliti melakukan perancangan basis data, perancang antarmuka.

4. Coding (Pengkodean), pada tahap ini peneliti melakukan proses pengkodean untuk mengubah desain ke dalam bahasa pemrograman Visual Basic 6.0.

5. Testing, pada tahap ini peneliti melakukan pengujian terhadap program yang telah dibuat dengan metode black box testing.

\subsection{Alat Bantu Pengembangan Sistem}

Pengembangan sistem dilakukan dengan menggunakan alat bantu Diagram Alir Data (Data Flow Diagram), Diagram Hubungan Entitas (Entity Relationship Diagram), Kamus Data (Data Dictionary), perangkat keras, serta perangkat lunak dengan spesifikasi sebagai berikut :

\subsubsection{Perangkat Keras (Hardware)}

Untuk mendukung sistem tersebut dibutuhkan spesifikasi perangkat keras komputer minimal setara Pentium IV, sehingga proses pengolahan database dapat dilaksanakan tepat waktu. Perangkat keras yang digunakan oleh peneliti dalam pengembangan sistem adalah sebagai berikut :

- 1 Unit Notebook

- Sensor Beban (Load Cell)

- Printer

\subsubsection{Perangkat Lunak (Software)}

Sistem yang akan dibuat, hasilnya berupa sistem perangkat lunak pengolahan data timbang dengan memakai bahasa pemrograman Visual Basic 6.0 pada PT Hindoli Banyuasin Palembang Sumatera Selatan. Perangkat lunak yang digunakan oleh peneliti dalam pengembangan sistem adalah :

- Sistem Operasi : Microsoft Windows Xp Profesional

- Bahasa Pemograman : Visual Basic 6.0

- Basis Data : MySQL

\subsection{Analisa Sistem Berjalan}

\subsubsection{Alur Kerja (Workflow) Sistem Berjalan}

1. Truk pengangkut Tandan Buah Segar (TBS) 
3.6.2 Flow of Document Sistem Berjalan

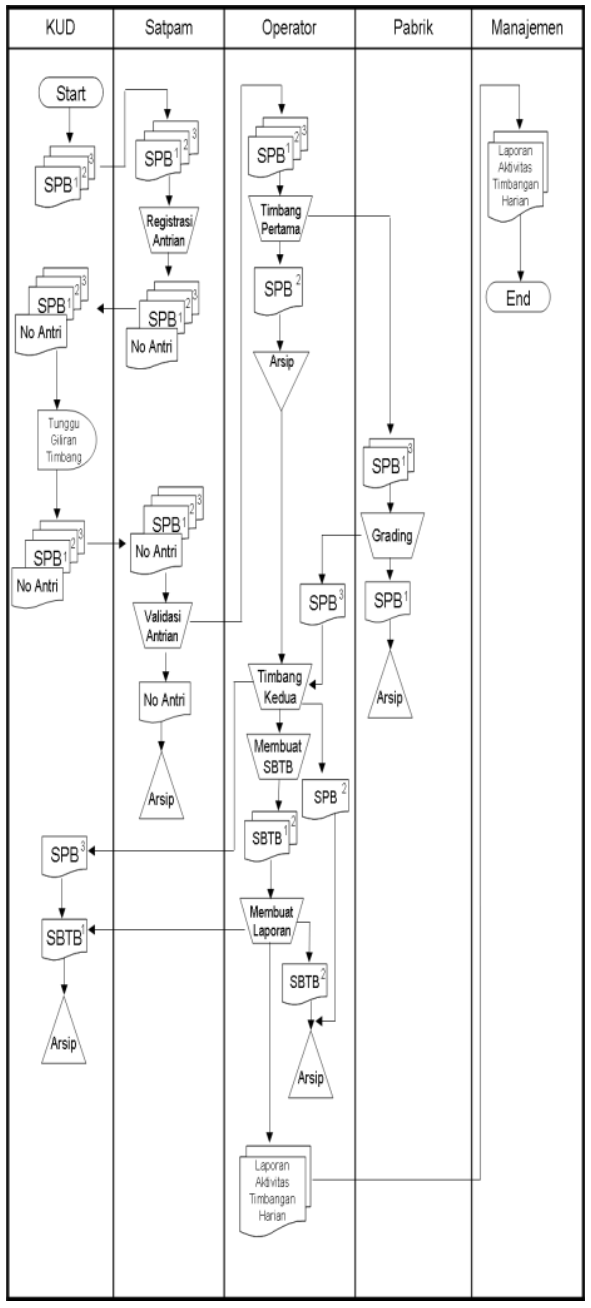

Keterangan:

TBS = Tandan Buah Segar Sawit

KUD = Koperasi Unit Desa

SPB = Surat Pengantar Buah

SBTB $=$ Surat Bukti Timbang Buah

No Antrian = Nomor Antrian

Grading = Uji Mutu TBS

\subsubsection{Diagram Alir Data (Data Flow Diagram) Sistem Berjalan}

\subsubsection{Contex Diagram}

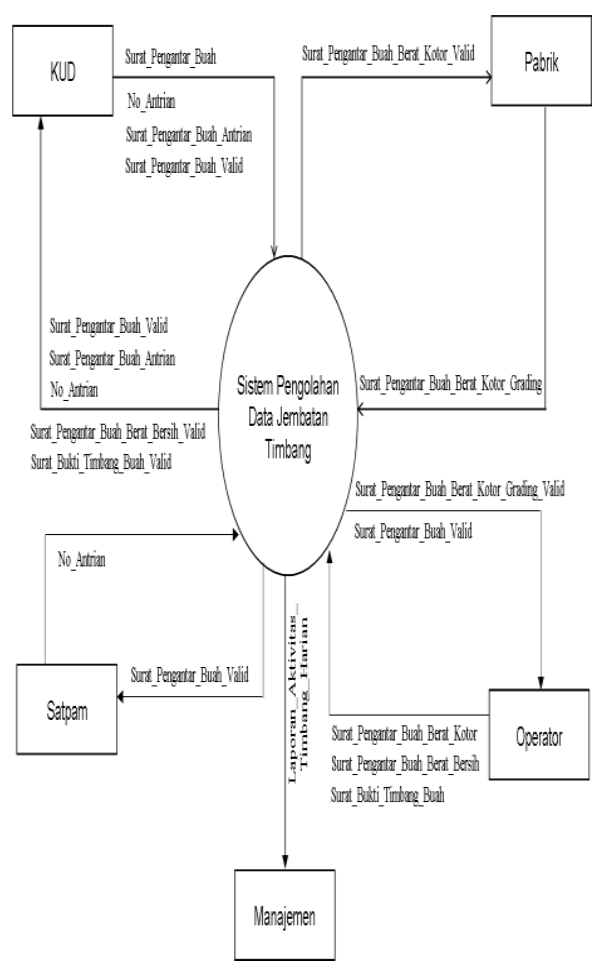

Gambar 3.2 Context Diagram - Sistem Berjalan

\subsubsection{Diagram Zero}

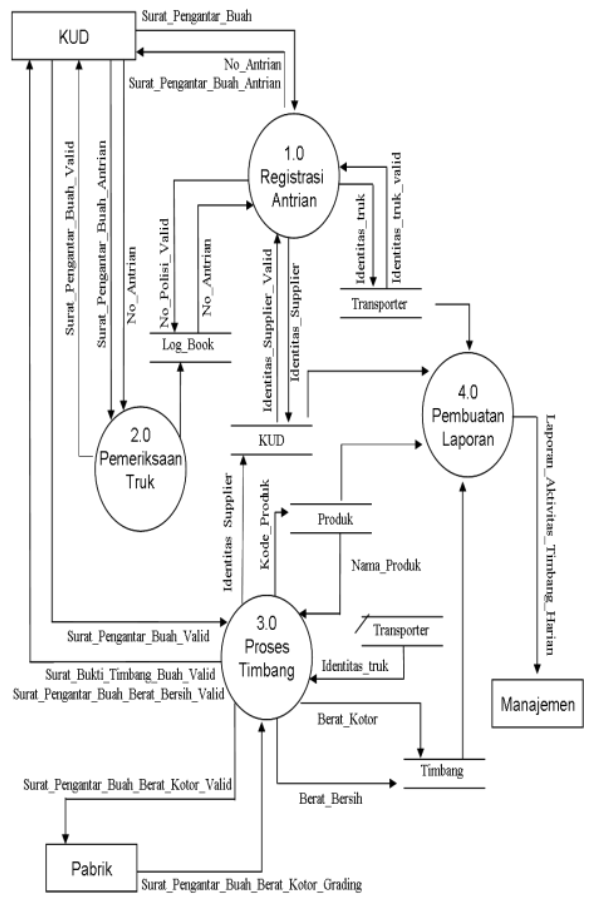

Gambar 3.3 Diagram Zero - Sistem Berjalan 
3.6.3.3 Diagram Level 1 Registrasi Antrian

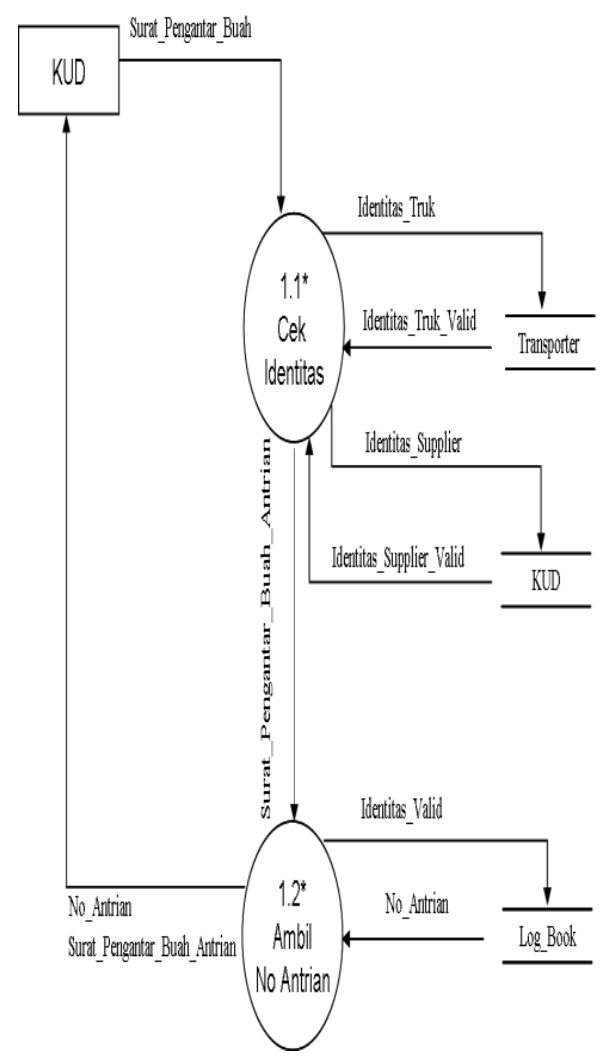

Gambar 3.4 Diagram Level 1 Registrasi Antrian - Sistem Berjalan

3.6.3.4 Diagram Level 1 Pemeriksaan Truk

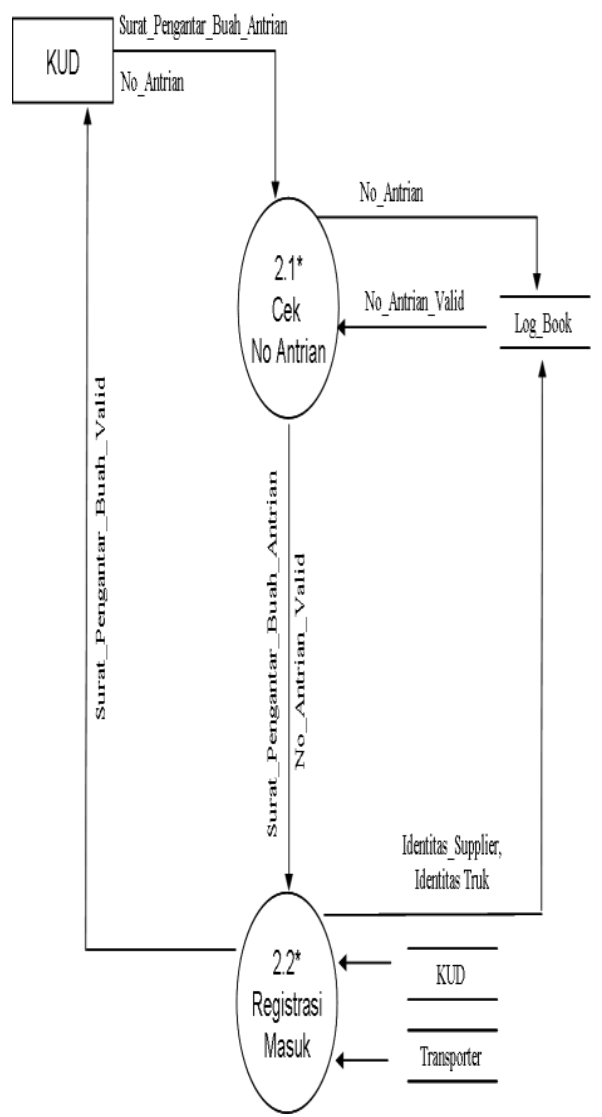

Gambar 3.5 Diagram Level 1 Pemeriksaan Truk - Sistem Berjalan

3.6.3.5 Diagram Level 1 Proses Timbang

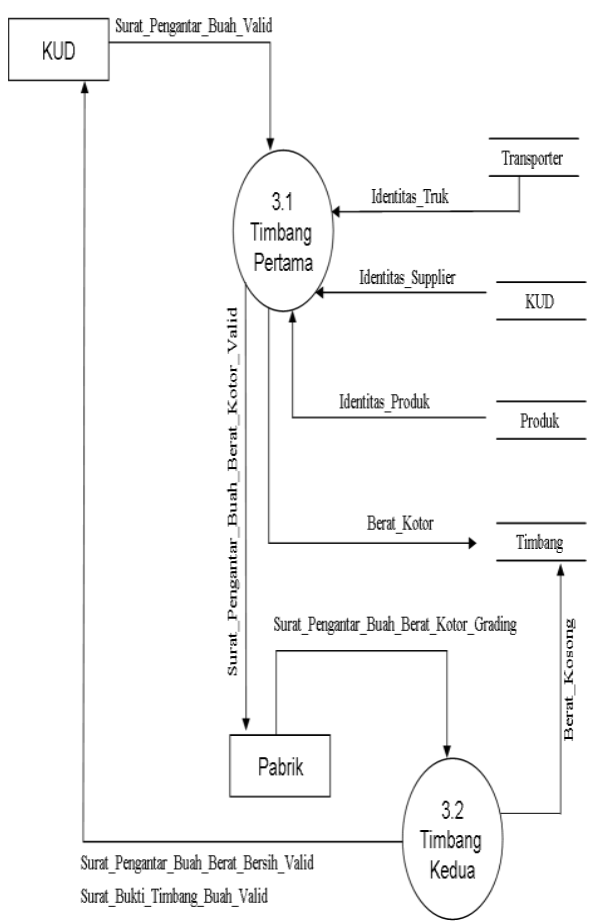


Gambar 3.6 Diagram Level 1 Proses Timbang Sistem Berjalan

\subsubsection{Diagram Level 2 Timbang Pertama}

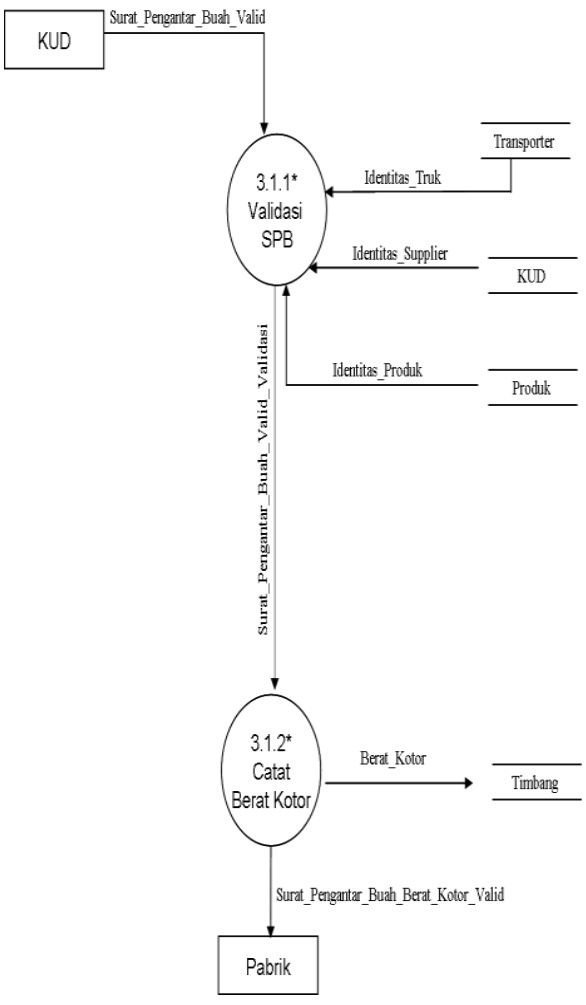

Gambar 3.7 Diagram Level 2 Timbang PertamaSistem Berjalan

3.6.3.7 Diagram Level 2 Timbang Kedua

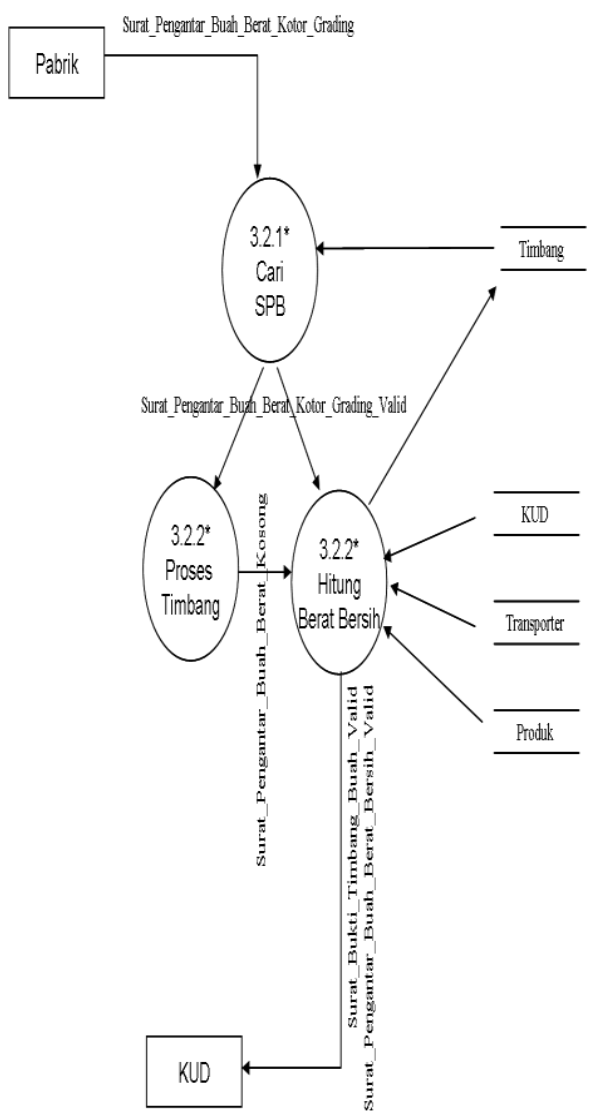

Gambar 3.8 Diagram Level 2 Timbang Kedua Sistem Berjalan

\subsubsection{ERD (Entity Relationship Diagram)} Data Timbang 


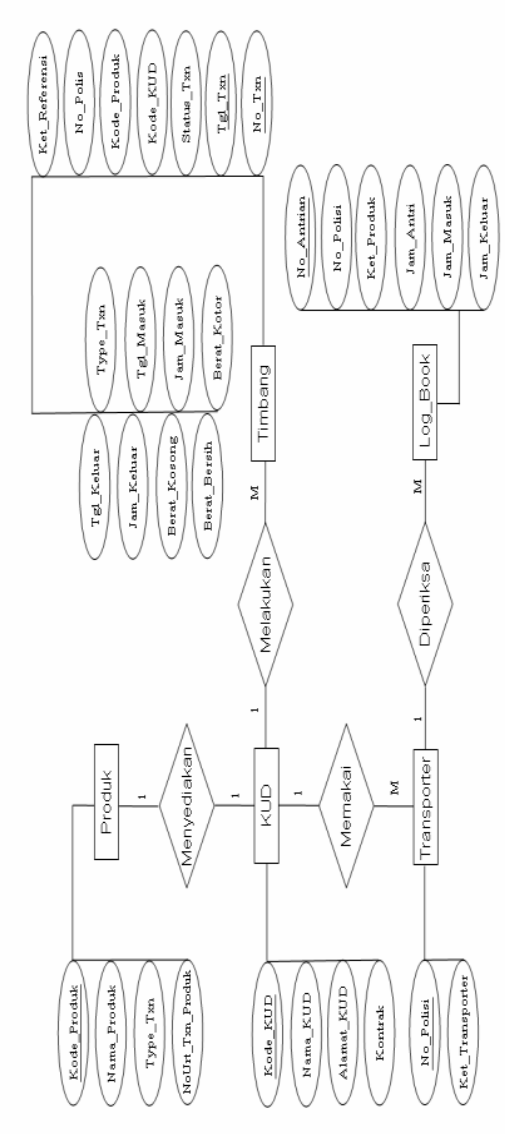

Gambar 3.9 ERD Sistem Pengolahan Data Jembatan Timbang - Sistem Berjalan

\subsection{Kelemahan Sistem Berjalan}

Kelemahan pada sistem yang sekarang berjalan antara lain, pencatatan data timbangan yang kurang akurat, proses pelaporan dibutuhkan waktu yang lama serta sering terjadi kesalahan karena faktor sumber daya manusia yang kurang teliti dan sistem pendataan yang masih dilakukan secara manual.

Sistem yang sedang berjalan mudah terjadi kolusi antara petugas operator timbang dengan supir truk pengangkut TBS saat proses penimbangan berlangsung dalam hal pencatatan angka timbang.

\subsection{Kelebihan Sistem Berjalan}

Selain kelemahan, sistem yang sedang berjalan juga terdapat kelebihan yaitu mudah dalam operasional, hal ini disebabkan dalam pengolahan data timbang tidak dibutuhkan petugas yang menguasai komputer dan prosedur kerja yang masih sederhana. Mudah mencari petugas pengganti untuk mengantikan operator yang tidak dapat melaksanakan tugas pada waktu tertentu.

\subsection{Usulan Sistem Yang Digunakan}

Untuk mengatasi kelemahan-kelemahan sistem yang sekarang berjalan, maka diusulkan untuk mengembangkan sistem pengolahan data yang terkomputerisasi. Berikut ini beberapa alternatif usulan :

\subsubsection{Alternatif Usulan Menggunakan Multi User}

Multi user adalah suatu program yang dapat diakses oleh beberapa pemakai melalui jaringan dan dilakukan dalam waktu bersamaan.

\subsubsection{Spesifikasi Perangkat yang Dibutuhkan Multi User}

1. Perangkat Keras (Hardware) yang dibutuhkan minimal 1 unit server dan 1 unit workstation yaitu :

- Satu unit Server (komputer induk), dengan spesifikasi minimum sebagai berikut:

○ Processor minimal 2.2 Ghz atau yang lebih cepat, setara Pentium 4 Core 2 Duo atau lebih.

○ Switch Hub 4 port

○ Sebuah Harddisk berkapasitas 250GB

- Perangkat rekam piringan cakram DVD-RW untuk keperluan backup data

- Memory RAM komputer minimal 2GB

- Mempunyai Ethernet Card.

- Monitor 15" CRT (Cathode Ray Tube)

- Keyboard $101 \mathrm{Key}$

- Mouse Scroll Ps/2

- UPS 600VA

- Printer Laser ukuran kertas A4 
- Empat unit Workstation (Komputer Kerja) untuk digunakan pada bagian Satpam, Operator, Pabrik dan Manajemen untuk keperluan memasukkan data dan laporan, dengan spesifikasi minimum sebagai berikut :

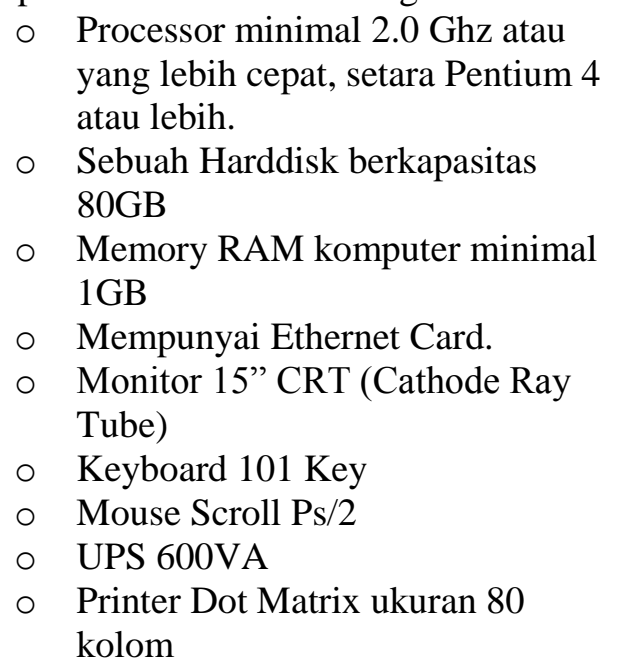

2. Perangkat Lunak (Software) yang dibutuhkan yaitu :

a. Sistem Operasi Windows 2003 Server, untuk digunakan pada komputer induk (Server).

b. Sistem Operasi Windows Xp, untuk digunakan pada komputer kerja (Workstation).

c. Bahasa Pemrograman Microsoft Visual Basic 6.0

d. Program Aplikasi Sistem Informasi Pengolahan Data Timbang Pabrik Minyak Sawit (CPO Mill) dengan bahasa pemrograman Visual Basic 6.0 pada PT Hindoli Banyuasin Palembang Sumatera Selatan.

\subsubsection{Kelebihan Program Menggunakan Multi User}

1. Data timbang dapat digunakan secara bersama-sama dengan bagian lain, seperti bagian pembukuan dalam membuat proses pembayaran ke petani tanpa harus menanyakan pada bagian timbang.

2. Memudahkan dan mempercepat proses pelaporan untuk analisis data timbang, karena dapat dikerjakan memakai komputer kerja pada bagian lain yang terhubung ke jaringan tersebut.

3. Menghilangkan pekerjaan pengulangan input data yang sama dalam proses pembuatan laporan dan penyajian data timbang lebih akurat karena terhindar dari faktor kesalahan manusia, misalnya faktor kurang teliti atau faktor kelelahan.

4. Proses analisis data timbang dapat dilakukan secara seketika.

\subsubsection{Kekurangan Program Menggunakan Multi User}

1. Resiko yang terjadi pada sistem informasi pengolahan data timbang Pabrik Minyak Sawti (CPO Mill) pada PT Hindoli yang berbasis komputer khususnya dalam hal jaringan komputer adalah keamanan data.

2. Data yang sama dapat diakses memakai komputer yang terhubung ke jaringan tersebut membuat virus komputer mudah menyebar dan resiko keamanan data dari pencurian pihak yang tidak bertanggung jawab.

\subsubsection{Alternatif Usulan Menggunakan Single User}

Single User adalah suatu program yang dapat diakses oleh seorang pemakai sehingga pemakai lain yang ingin mengakses program tidak dapat dilakukan karena dibatasi penggunaannya.

\subsubsection{Spesifikasi Perangkat yang Dibutuhkan Single User}

1. Perangkat Keras (Hardware) yang dibutuhkan minimal dengan spesifikasi sebagai berikut :
a. Processor minimal $2.0 \mathrm{Ghz}$ atau diatasnya, setara Pentium 4.
b. Sebuah Harddisk berkapasitas 80GB
c. Memory RAM komputer minimal 1GB
d. Printer Dot Matrix minimal 80 kolom.

2. Perangkat Lunak (Software) yang dibutuhkan yaitu : 

a. Sistem Operasi Windows Xp, untuk digunakan pada komputer kerja (Workstation).
b. Bahasa Pemrograman Microsoft Visual Basic 6.0
c. Program Aplikasi Sistem Informasi bahasa pemrograman Visual Basic 6.0 Sumatera Selatan. Pengolahan Data Timbang Pabrik Minyak Sawit (CPO Mill) dengan pada PT Hindoli Banyuasin Palembang

\subsubsection{Kelebihan Program Menggunakan Single User}

1. Kelebihan menggunakan program single user adalah tidak adanya ganguan sistem komputer yang datang dari lingkungan luar.

2. Keamanan data penting perusahaan terjamin kerahasiaannya.

\subsubsection{Kekurangan Program Menggunakan Single User}

1. Data timbang hanya dapat diakses pemakai komputer tersebut.

2. Program Aplikasi Sistem Pengolahan Data Timbang Pabrik Minyak Sawit (CPO Mill) pada PT Hindoli masih sederhana sehingga kepuasan pihak-pihak yang terlibat dalam sistem ini tidak dapat terpenuhi, khususnya para pemakai akhir (End User).

\subsubsection{Rekomendasi Sistem yang Akan Digunakan}

Peneliti rekomendasikan untuk memakai alternatif usulan menggunakan sistem multi user karena dilihat dari kebutuhan bagian pengolahan data timbang PT Hindoli dan ketersediaan sumber daya yang ada.

\section{PEMBAHASAN}

\subsection{Sejarah Singkat}

PT Hindoli merupakan anak perusahaan PT Cargill Indonesia yang berlokasi di jalan Lintas Timur Palembang Jambi, tepatnya berada di Kabupaten Musi Banyuasin, Kecamatan Sungai Lilin, Palembang, Sumatera Selatan. Perusahaan ini bergerak dalam usaha perkebunan sawit dan pabrik pengolahan menjadi minyak kelapa sawit (Crude Palm Oil/CPO Mill). PT Hindoli di akuisisi oleh PT Cargill Indonesia tahun 1995 dengan alamat kantor pusat di Plaza Bapindo, Citibank, Tower, Lt.23 Jl. Jend. Sudirman Kav. 54-55 Jakarta-12190. Perancangan Output

\subsubsection{Output Cetakan}

a. Weighing Ticket (Surat Bukti Timbang Buah), lihat lampiran Al.

b. Daily Operator Activity Report (Laporan Harian Aktivitas Operator), lihat lampiran A2.

c. Weighing Activity Report By Product (Laporan Aktivitas Timbang Berdasarkan Produk), lihat lampiran A3.

d. Weighing Activity Report By Transporter (Laporan Aktivitas Timbang Berdasarkan Transporter), lihat lampiran A4.

e. Weighing Activity Report By Customer (Laporan Aktivitas Timbang Berdasarkan Pelanggan), lihat lampiran A5.

f. Weighing Activity Report By Vehicle (Laporan Aktivitas Timbang Berdasarkan Kendaraan), lihat lampiran A6.

g. Weighbridge Summary Report By Transporter (Rekap Data Timbang Berdasarkan Transporter), lihat lampiran A7.

h. Weighbridge Summary Report By Customer, lihat lampiran A8.

i. Weighbridge Summary Report By Month (Rekap Data Timbang Per Bulan), lihat lampiran A9.

\subsubsection{Output Layar}

a. Daily Transaction Summary (Rekap Transaksi Harian), lihat lampiran A10.

$b$. Weighbridge Activity Report (Laporan Aktivitas Timbang), lihat lampiran All.

\subsection{Perancangan Proses}

\subsubsection{Perancangan Alir Kerja (Workflow)}

Perancangan Alir kerja (workflow) sistem pada pengolahan data timbang PT Hindoli sebagai berikut : 


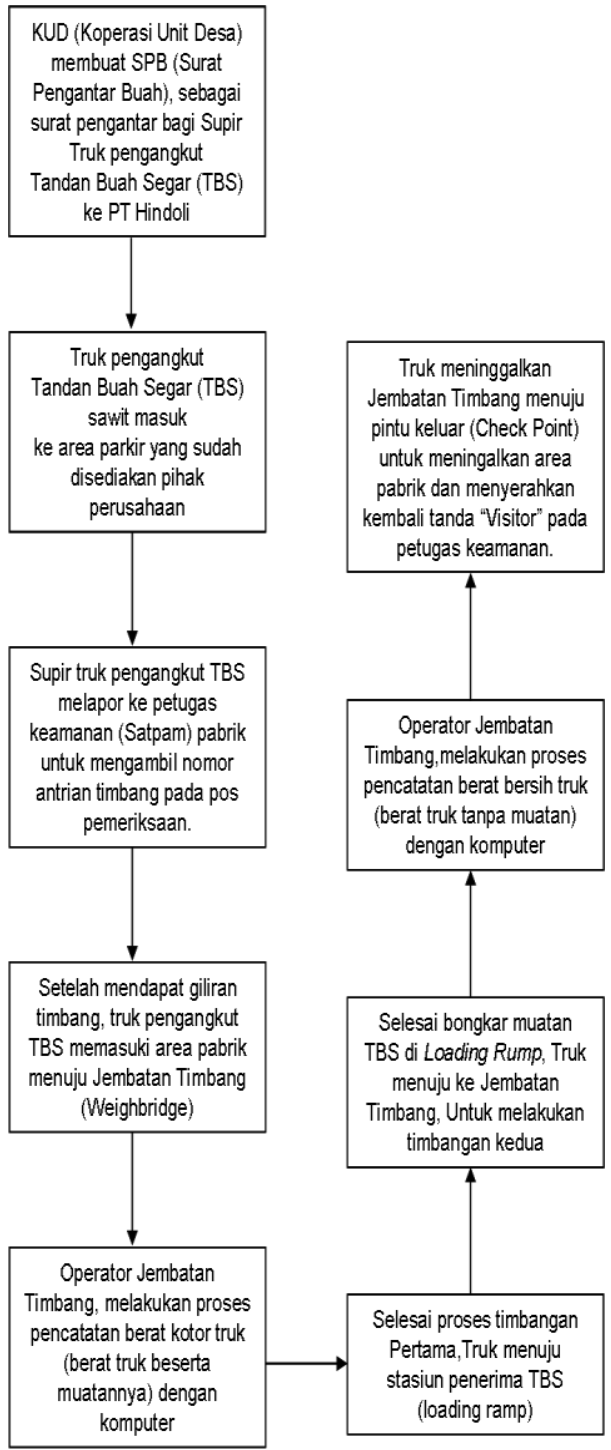

Gambar 4.2 Perancangan Alir Kerja (Workflow) Sistem

1. Koperasi Unit Desa (KUD) membuat Surat Pengantar Buah (SPB) sebagai surat pengantar bagi supir truk pengangkut Tandan Buah Segar (TBS) sawit ke PT Hindoli.

2. Truk pengangkut Tandan Buah Segar (TBS) sawit masuk ke area parkir yang sudah disediakan pihak PT Hindoli.

- TBS sawit bisa berasal dari petani plasma, perkebunan inti, atau perusahaan perkebunan lainnya sebagai supplier TBS sawit ke PT Hindoli.

- Dalam melayani truk pengangkut TBS, perusahaa PT Hindoli memakai prinsip First Come First Serve (FCFS), truk yang datang duluan akan mendapat giliran timbang terlebih dahulu.

- Area parkir berada diluar pagar lokasi pabrik sawit (CPO Mill), hal ini dilakukan demi ketertiban antrian truk dan keamanan pabrik dari pihak luar perusahaan.

3. Supir truk pengangkut TBS melapor ke petugas keamanan (Satpam) pabrik untuk mendapatkan nomor antrian timbang pada pos pemeriksaan.

- Pos pemeriksaan terletak disisi pintu masuk area pabrik.

- Satpam memberikan nomor urut antrian dan mencatat identitas mobil (no plat polisi dan supir) kedalam $\log$ book.

- Pada puncak musim panen, antrian bisa berlangsung 3 sampai 4 jam, dikarenakan berlimpahnya TBS sawit.

4. Setelah mendapat giliran timbang, Truk pengangkut TBS memasuki area pabrik menuju Jembatan Timbang (Weighbridge).

- Petugas keamanan melakukan pemeriksaan secara fisik terhadap truk dan muatannya.

- Memeriksa kelengkapan Surat Pengantar Buah (SPB).

- Setelah pemeriksaan dan dinyatakan siap timbang, petugas mencatat jam masuk dan meminta supir truk membubuhkan tandatangan dan mengenakan tanda pengenal sebagai tamu (Visitor) selama berada di dalam lokasi pabrik.

- Truk diparkir di atas jembatan timbang pada posisi siap timbang.

- Supir menuju ke loket petugas timbang dan menyerahkan Surat Pengantar Buah (SPB) 3 rangkap.

- Rangkap pertama (warna putih), rangkap kedua (warna kuning), rangkap ketiga (warna merah).

5. Petugas operator jembatan timbang, melakukan proses pencatatan berat kotor truk (berat truk beserta muatannya) 
dengan bantuan aplikasi komputer Sistem Pengolahan Data Timbang.

- Pencatatan berat kotor ini disebut timbangan pertama (First Weighing).

- Rangkap kedua (warna kuning) dan ketiga (warna merah), akan diserahkan kembali ke supir sebagai pengantar kepada petugas Loading Ramp (Stasiun Penerima TBS) dan bongkar muatan TBS.

- Rangkap pertama (warna putih) akan diarsip sementara oleh petugas sampai timbangan kedua (Second Weighing) .

6. Selanjutnya, truk menuju Stasiun Penerima TBS (Loading Ramp).

- Supir menyerahkan SPB rangkap kedua (warna kuning) dan rangkap ketiga (warna merah) kepada petugas Loading Ramp.

- Petugas Loading Ramp memerika kelengkapan SPB, setelah itu menurunkan TBS

- Selesai bongkar muatan TBS, petugas Loading Ramp membubuhkan paraf pada SPB rangkap kedua (warna kuning) dan ketiga (warna merah), sebagai bukti Stasiun Penerima TBS (Loading Ramp) sudah menerima muatan TBS.

- Rangkap kedua (warna kuning), disimpan sebagai arsip pada bagian administrasi Loading Ramp.

- Rangkap ketiga (merah), dikembalikan ke supir sebagai pengantar ke bagian jembatan timbang (Weighbridge) untuk dilakukan proses timbang kedua (Second Weighing).

7. Selesai bongkar muatan TBS di Loading Rump, Truk menuju ke Jembatan Timbang, untuk melakukan proses timbangan kedua.

- Supir membawa SPB rangkap ketiga (warna merah) menuju Jembatan Timbang untuk melakukan proses penimbangan berat kosong kendaraan atau timbangan kedua.
8. Petugas operator Jembatan Timbang, melakukan proses pencatatan berat bersih truk (berat truk tanpa muatan) dengan bantuan aplikasi komputer Sistem Pengolahan Data Timbang.

- Petugas mencari rangkap pertama (putih) SPB pada arsip sementara.

- Petugas memanggil kembali data timbang pertama dari komputer dengan kunci pencarian: No Kendaraan, untuk melakukan validasi SPB rangkap ketiga (warna merah) dengan data di komputer, dan SPB rangkap pertama (putih)

- Setelah validasi selesai, Petugas melakukan proses pencatatan berat kosong kendaraan (Second Weighing) dengan bantuan aplikasi komputer Sistem Pengolahan Data Timbang.

- Komputer akan melakukan kalkulasi Berat Kotor Kendaraan dikurangi Berat Kosong Kendaraan untuk mendapatkan Berat Bersih (Berat TBS)

- Operator membubuhkan paraf pada SPB rangkap ketiga (warna merah) sebagai tanda proses penimbangan sudah selesai dilakukan.

- Operator membuat Surat Bukti Timbang Buah (SBTB), sebanyak 2 rangkap.

- Supir membubuhkan tandatangan pada SBTB, sebagai tanda timbangan kedua selesai dan setuju dengan berat bersih tersebut.

- Rangkap ketiga (merah) SPB dan rangkap pertama (putih) SPB, diarsip petugas timbangan untuk diproses lebih lanjut dalam pembuatan laporan.

9. Supir meninggalkan jembatan timbangan menuju pintu keluar (Check Point) dan menyerahkan kembali tanda visitor pada petugas keamanan (Satpam), sekali lagi Satpam memeriksa secara fisik keadaan kendaraan, setelah dinyatakan Clear, supir membubuhkan tandatangan pada Log Book dan selanjutnya supir beserta truk meninggalkan lokasi pabrik.

\subsubsection{Perancangan Flow of Document Sistem}




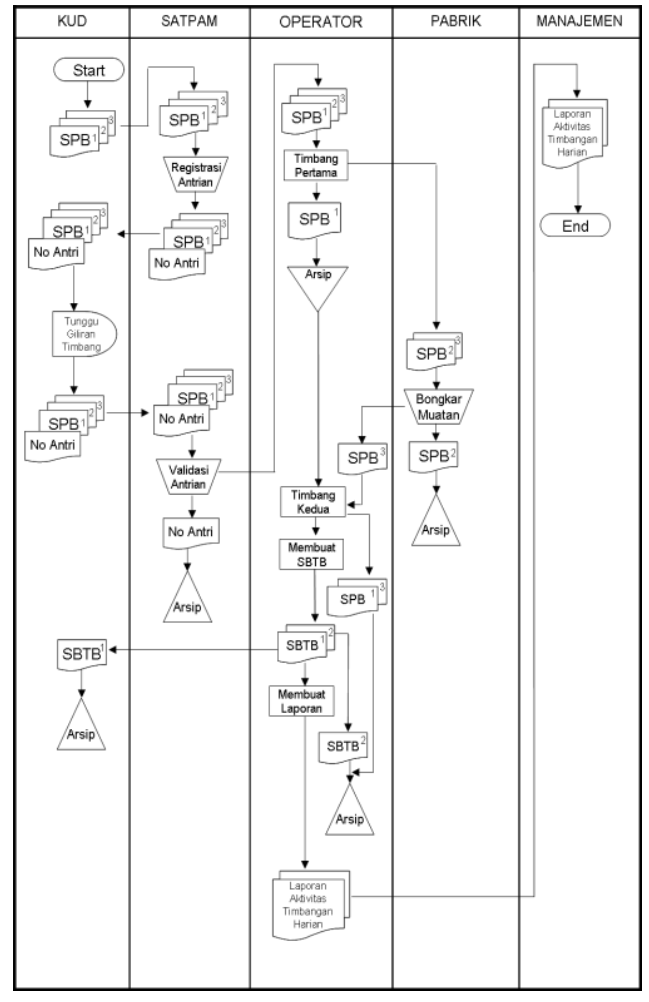

Keterangan:

TBS $=$ Tandan Buah Segar Sawit

KUD $=$ Koperasi Unit Desa

$\mathrm{SPB}=$ Surat Pengantar Buah

$\mathrm{SBTB}=$ Surat Bukti Timbang Buah

No Antri $=$ Nomor Antrian

\subsection{Perancangan Data Flow Diagram}

\subsubsection{Contex Diagram}

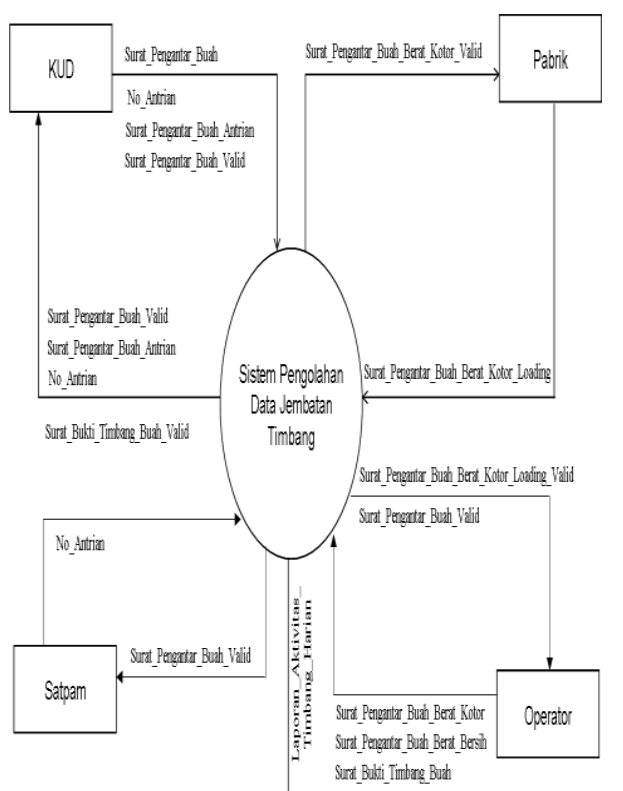

\subsubsection{Diagram Zero}

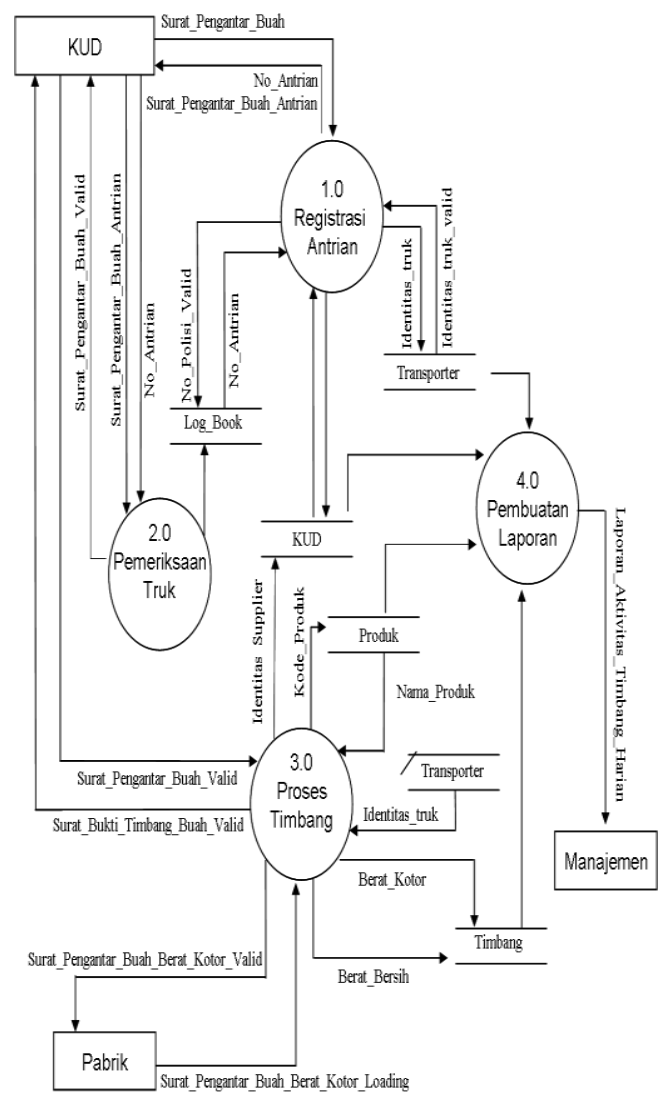

Gambar 4.4 Diagram Zero

4.3.3 Diagram Level 1 Registrasi Antrian

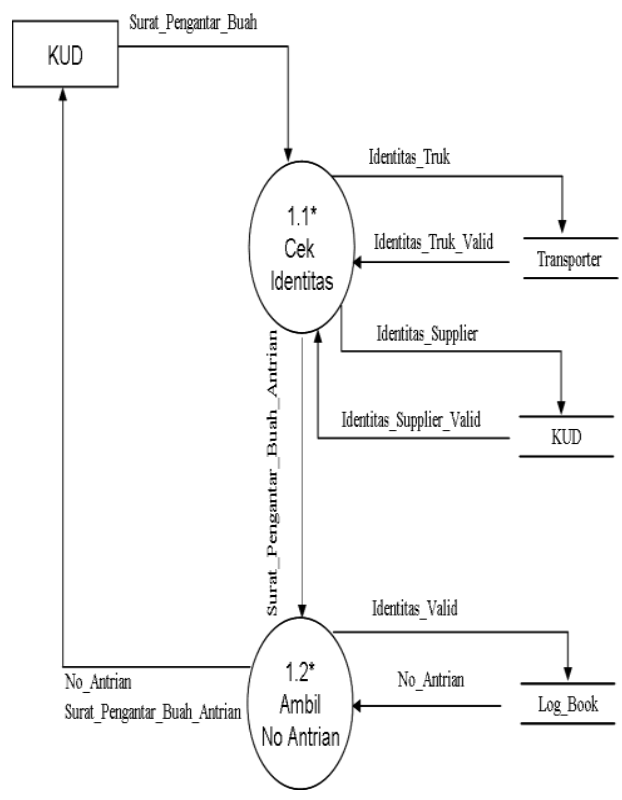


Gambar 4.5 Diagram Level 1 Registrasi Antrian

4.3.4 Diagram Level 1 Pemeriksaan Truk

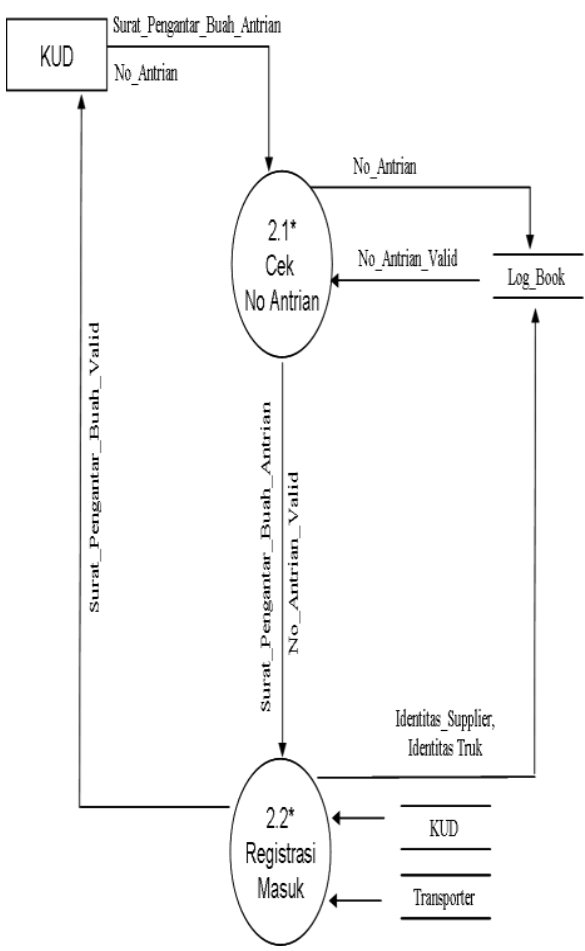

Gambar 4.6 Diagram Level 1 Pemeriksaan Truk

4.3.5 Diagram Level 1 Proses Timbang

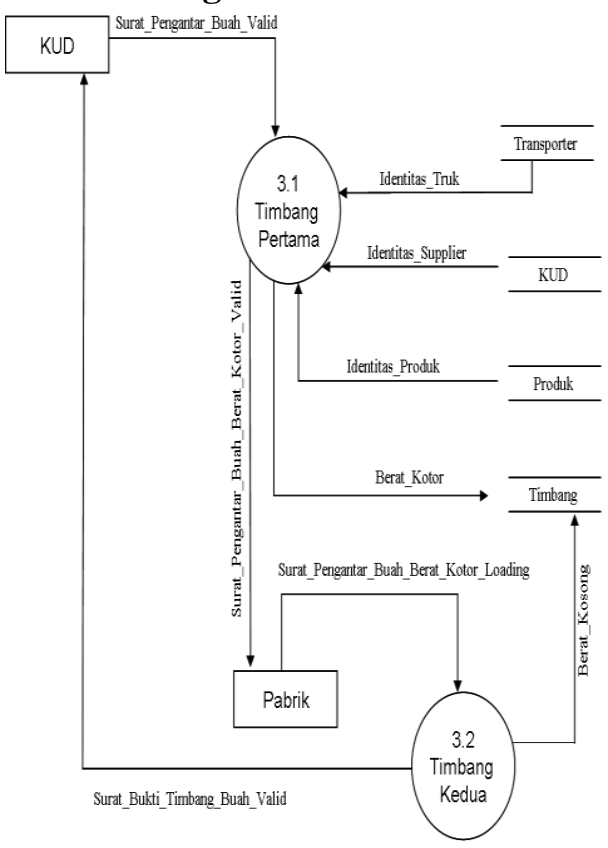

Gambar 4.7 Diagram Level 1 Proses Timbang

4.3.6 Diagram Level 2 Timbang Pertama

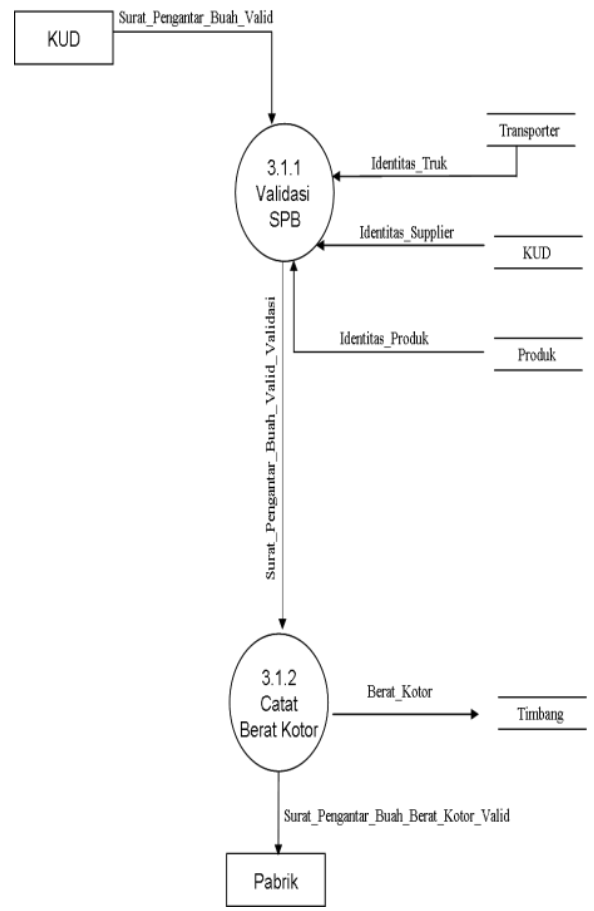

Gambar 4.8 Diagram Level 2 Timbang Pertama

4.3.7 Diagram Level 2 Timbang Kedua

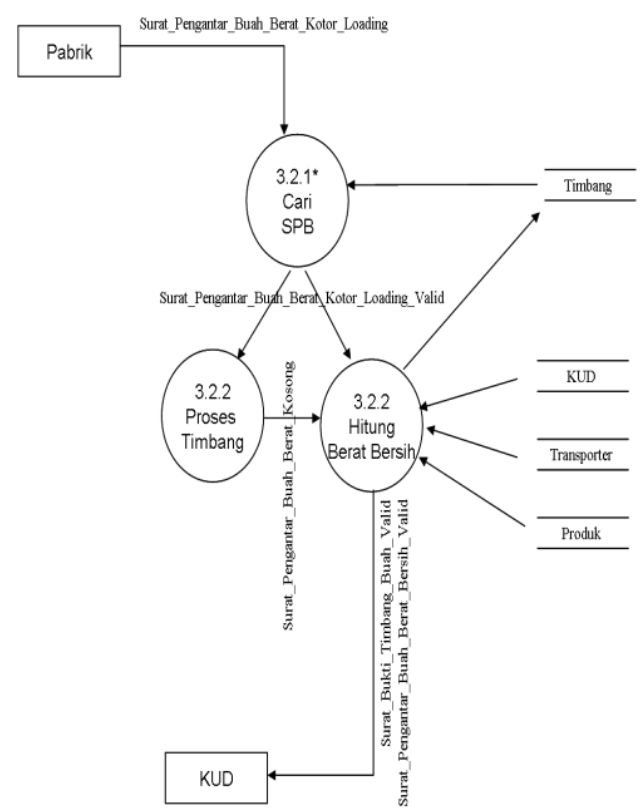

Gambar 4.9 Diagram Level 2 Timbang Kedua

4.4 ERD (Entity Relationship Diagram) Data Jembatan Timbang 


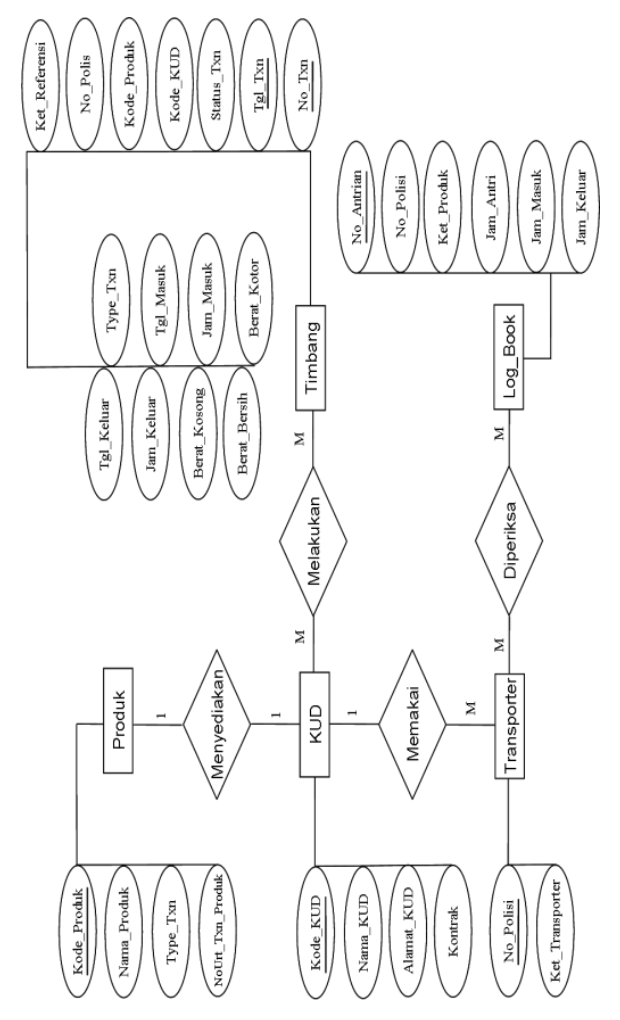

\subsection{Perancangan Input}

\subsubsection{Perancangan Input Transaksi}

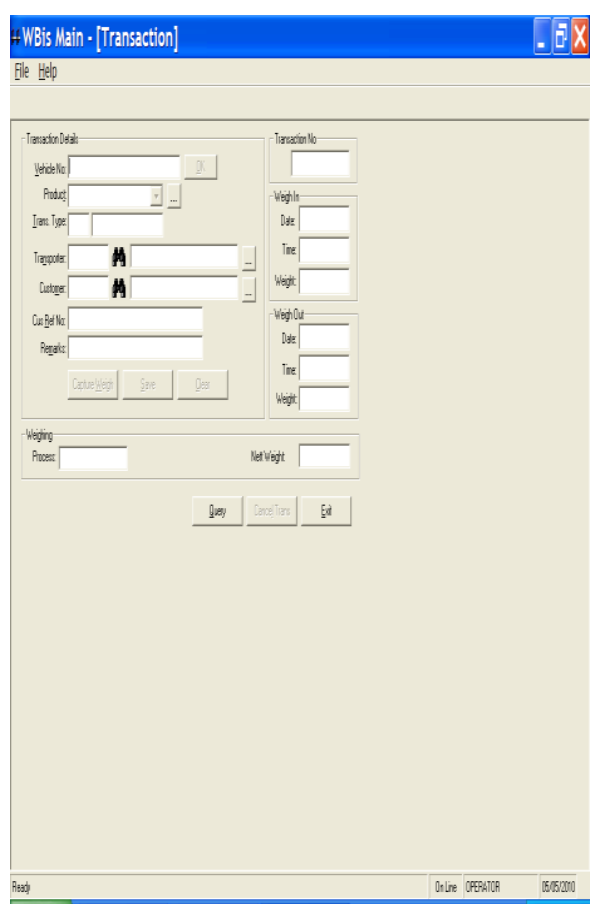

4.5.2 Perancangan Input Data Customer

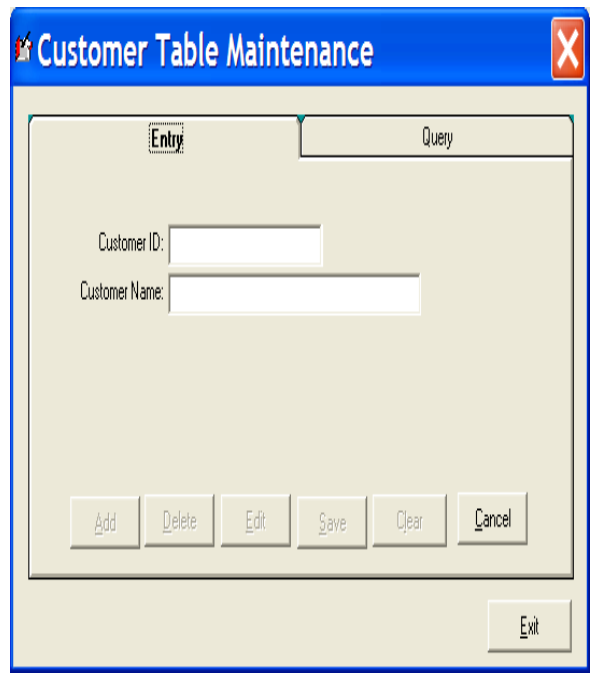

\subsubsection{Perancangan Input Data Transporter}

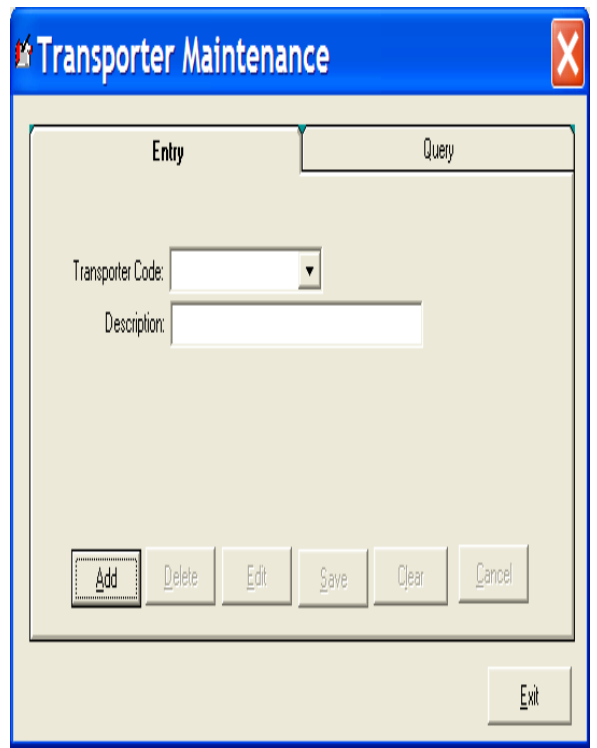

\subsection{Perancangan Menu}

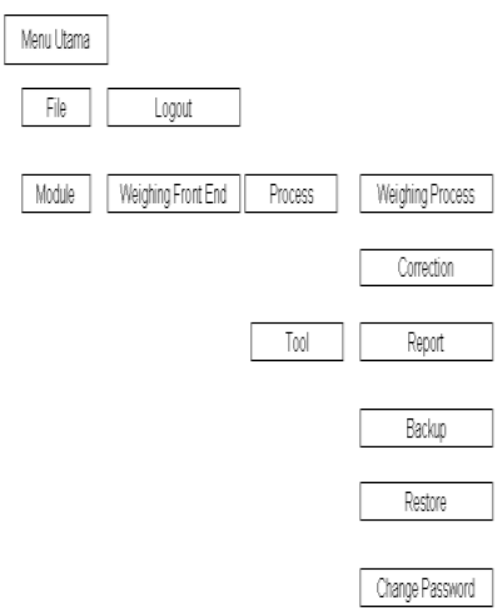




\subsubsection{Menu Utama}

Whathere

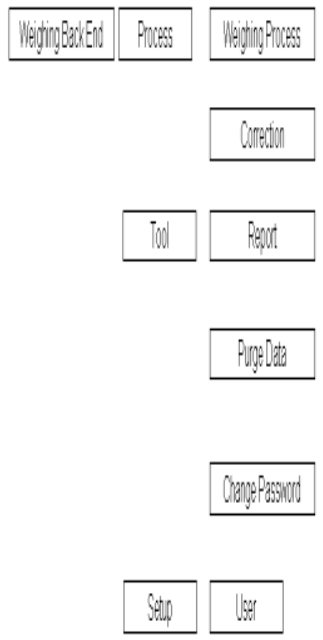

4.7 Flowchart Program

\subsubsection{Awal Program}

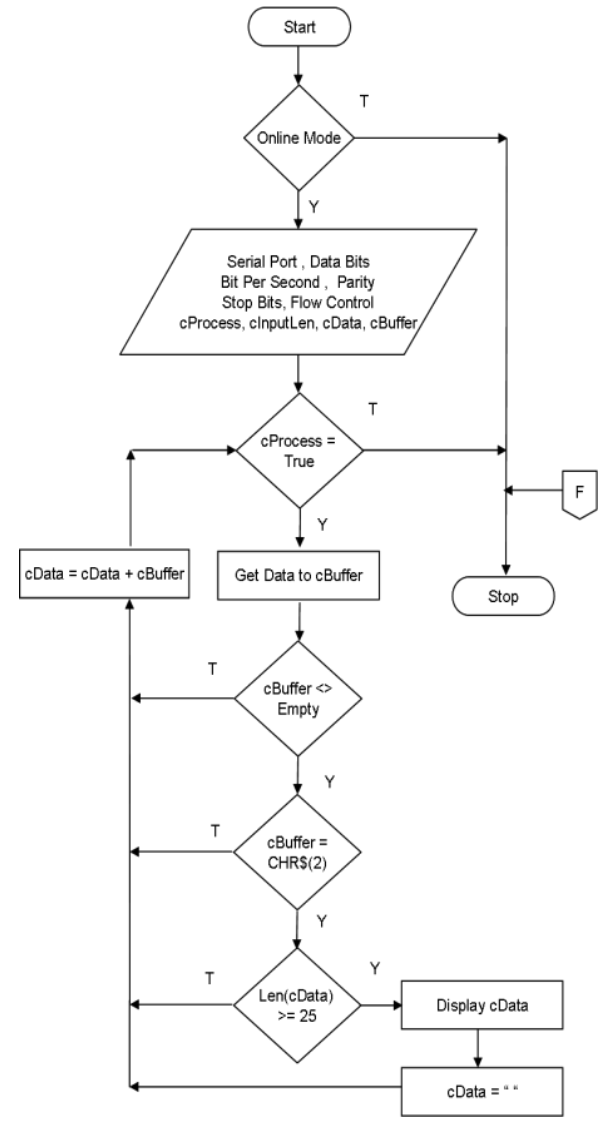

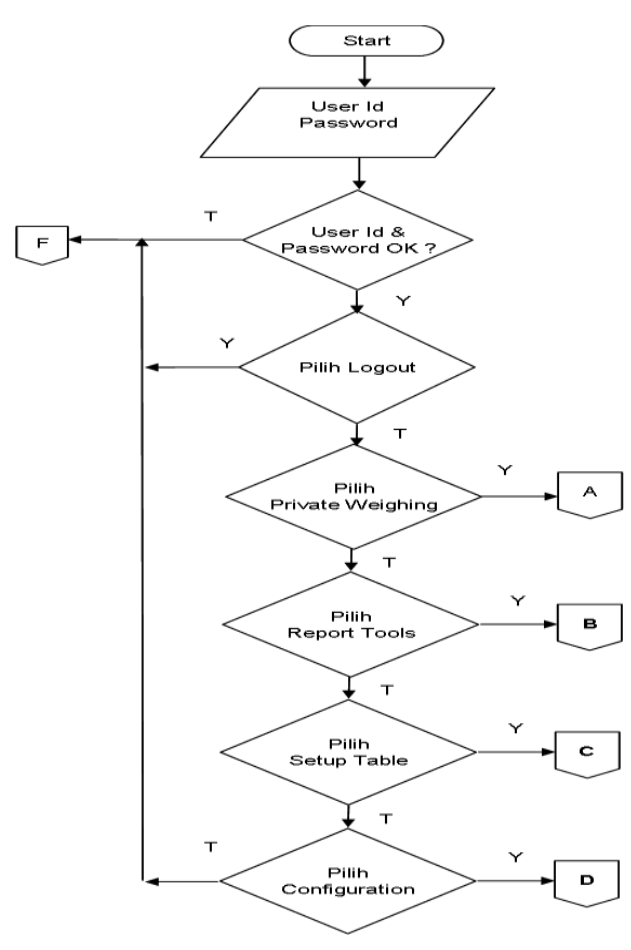

4.10.3 Private Weighing

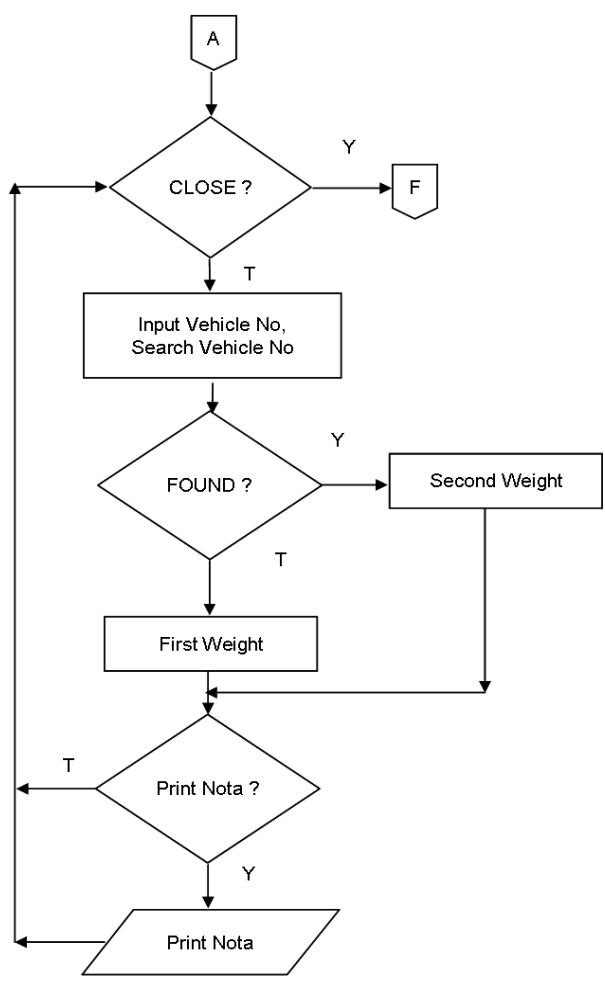

4.10.4 Report Tools 


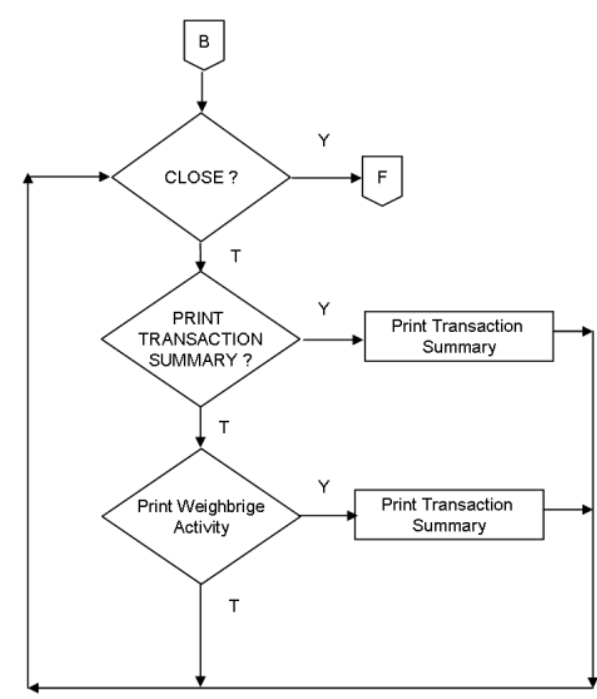

\subsubsection{Setup Table}

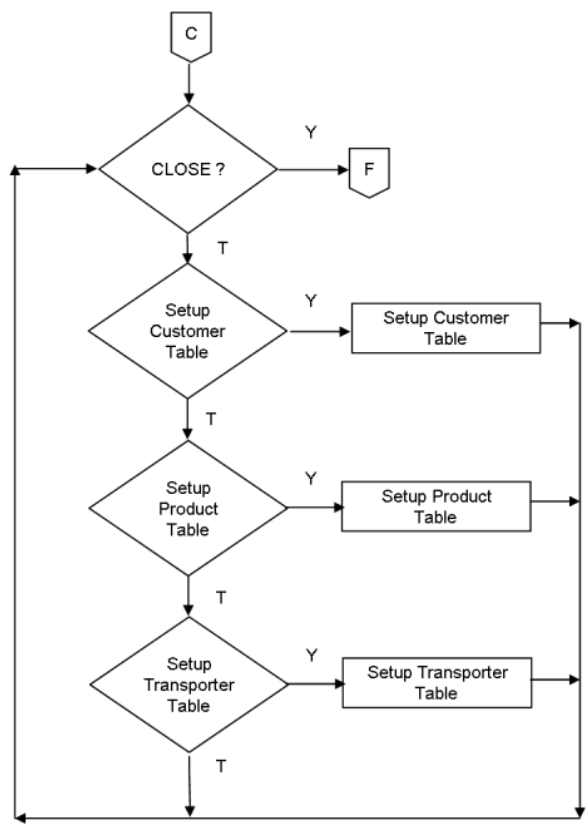

\subsubsection{Setup Configuration}

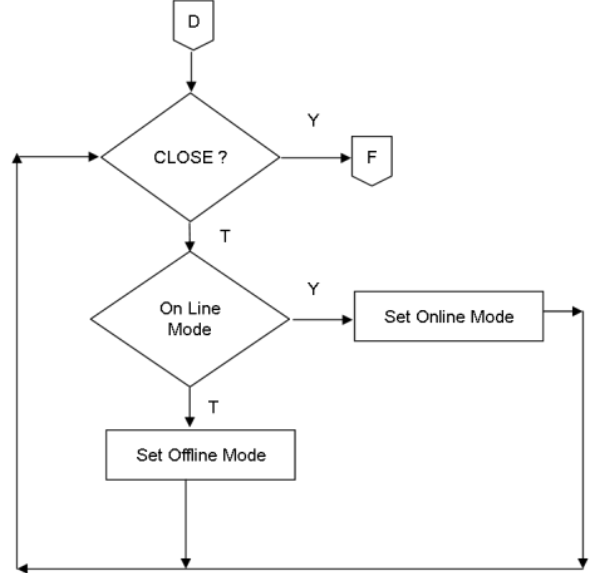

5. KESIMPULAN DAN SARAN

Setelah melakukan penelitian dan dari hasil pembahasan yang telah diuraikan, maka peneliti dapat menyimpulkan dan memberikan saran sehubungan dengan Perancangan Sistem Pengolahan Data Timbang Pabrik Minyak Sawit (CPO Mill) pada PT Hindoli Banyuasin Palembang Sumatera Selatan adalah sebagai berikut :

\subsection{Simpulan}

Beberapa simpulan yang dapat peneliti rangkum dengan adanya sistem pengolahan data timbang yang terintegrasi dengan data timbang secara terkomputerisasi, yaitu:

1. Meningkatkan produktivitas perusahaan dalam penyajian informasi yang cepat, tepat, akurat dan sesuai dengan kebutuhan.

2. Sistem aplikasi yang terintegrasi dengan data timbang sangat efektif menghindari faktor kesalahan manusia didalam proses pencatatan data timbang.

3. Integritas data timbang lebih terjamin terhadap petugas dilapangan.

\subsection{Saran}

Dengan diterapkannya sistem informasi pengolahan data timbang pabrik minyak sawit pada PT Hindoli Banyuasin Palembang Sumatera Selatan, ada beberapa saran yang dapat peneliti berikan, yaitu:

1. Diperlukan pelatihan-pelatihan menggunakan komputer serta aplikasi yang terkait didalamnya bagi calon operator. 
2. Perlu disiapkan pelatihan bagi beberapa operator jembatan timbang dalam mengoperasikan aplikasi yang telah dibuat dengan maksud untuk mengantisipasi apabila petugas operator yang bertugas tidak hadir kerja.

Diperlukannya petugas bagian EDP (Electronic Data Processing), yang dapat memelihara perangkat sistem komputer dan jaringan komputer yang ada.

\section{Daftar Pustaka}

[1] Jogiyanto HK, MBA, Akt.Prof. 2005. Sistem Teknologi Informasi. Andi Offset, Yogyakarta.

[2] Adi Nugroho,ST.,MMSI. 2004. Analisis dan Perancangan Sistem Informasi. Informatika, Bandung.

[3] Hanif Al Fatta 2007. Analisa \& Perancangan Sistem Informasi . Andi Offset Yogyakarta.

[4] Janner Simarmata . 2006. Basis Data. Andi Offset, Yogyakarta.

[5] I Made Wirartha, M.Si. 2006. Pedoman Penelitian Usulan Penelitian, Penelitian dan Tesis. Andi Offset, Yogyakarta.

[6] Jogiyanto, 1990. Analisis dan Disain Sistem Informasi. Andi Offset, Yogyakarta.

[7] Budi Sutedjo DO, S.Kom,MM, 2002. Perancangan dan Pengembangan Sistem Informasi. Andi Offset, Yogyakarta.

[8] Abdul Kadir, 2003. Pengenalan Sistem Informasi. Andi Offset, Yogyakarta.

[9] Edward Yourdon, 1989. Modern Structure Analysis. Prentice Hall Inc.

[10] Roger S. Pressman, 2002. Rekayasa Perangkat Lunak. Penerbit Andi Yogyakarta.

[11] Sutarto. 1978. Dasar-Dasar Organisasi : Gajah Mada University Press. 